siderable hazard. ${ }^{4} 5$ It must be carefully monitored and clotting factors and platelet concentrates given as soon as they are indicated.

${ }^{1}$ Reid HA, Nkrumah FK. Fibrin degradation products in cerebral malaria. Lancet $1972 ; \mathrm{i}: 218-21$.

${ }^{2}$ Jaroonkesama N. Intravascular coagulation in falciparum malaria. Lancet $1972 ; \mathrm{i}: 221-3$.

${ }^{3}$ Preston FE, Edwards IR. The successful use of streptokinase in a patien with purpura fulminans. $\mathrm{Br}$ Med F 1973;iii :329-30.

- Martindale W. Streptokinase. Extra Pharmacopoeia, 27th ed. London Pharmaceutical Press, 1977:583-6.

${ }^{5}$ Bell WR, Meek AG. Guidelines for the use of thrombolytic agents. $N$ Englf Med 1979;301:1266-70.

(Accepted 12 February 1980)

Department of Medicine, University of Rhodesia, Avondale, Salis bury, Zimbabwe

I R EDWARDS, MB, MRCP, professor and head of department) (present appointment: consultant physician and senior lecturer in clinical pharmacology University of Leicester, Medical Sciences Building, University Road, Leicester)

\section{Community study of hypothyroidism in Down's syndrome}

Down's syndrome is associated with autoimmune diseases affecting the thyroid, pancreas, gastric mucosa, and adrenal glands. Mongols have an increased tendency to produce thyroid antibodies. ${ }^{1}$ Sare et $\mathrm{al}^{2}$ found thyroid abnormality in 20 of 121 patients between the ages of 13 and 48 years-19 had thyroid deficiency and one hyperthyroidism. Moreover, diabetes mellitus is associated, with Down's syndrome and hypothyroidism. ${ }^{3}$

\section{Patients, methods, and results}

This report summarises the findings of our thyroid investigation on all children aged over 5 years and adults with Down's syndrome living in the southern district of Bedfordshire Area Health Authority. Their names were obtained from the handicap register and from the education and social services departments of the Bedfordshire County Council. Some lived at home or in hostels, others were at a MacIntyre Trust school. There is no hospital for residential care of the mentally subnormal in the district. The only bias in selection was the exclusion of children aged under 5 years. The authorities and the parents gave permission for a general examination, blood and urine tests, and recording of heights, weights, and dates of birth. The blood samples were examined by radioimmunoassay. Thyroxine (normal range $60-180 \mathrm{nmol} / 1 \quad(4 \cdot 7-14 \cdot 2 \mathrm{mg} / 100 \mathrm{ml})$ ), thyrotrophin (normal range $<1-8 \mathrm{mU} / \mathrm{l}$ ), and thyroid antibodies (thyroglobulin and thyroid microsomal antibodies) were measured with the Thymune- $T$ and Thymune-M haemagglutination kits.
The total number of patients studied was 101 (64 male, 37 female) There were 45 in the age group 5-14 years, 38 in the age group 15-21 years, and 18 in the age group $22-47$ years. Thirty of the 101 gave positive results in thyroid antibody tests-14 (31\%) out of the 45 in the age group 5-14 years, $8(21 \%)$ out of the 38 in the $15-21$-year group, and $8(44 \%)$ of the 18 in the 22-47-year group. The microsomal antibody tests gave positive results most often in 30 patients, and the thyroglobulin test was positive in only 5 . Seven patients had biochemical evidence of gross hypothyroidism (table) and were treated. Antibodies were present in all. Nine patients had evidence of borderline hypothyroidism and were not treated. Three of these patients had antibodies and six did not.

\section{Comment}

Few teenage and adult patients with Down's syndrome are seen regularly. The difficulty in recognising hypothyroidism is the overlap of signs in a non-complaining patient. The patient with Down's syndrome is usually shorter than average; slower and less active; less alert; quieter, with a hoarser voice; and mentally subnormal. All these symptoms are also found in hypothyroidism. Early clinical diagnosis is therefore difficult. Measurement of blood concentrations of thyroxine, thyrotrophin, and thyroid antibodies is essential.

A significant number of our patients (7 out of 101) with Down's syndrome had gross hypothyroidism, due mainly to autoimmune thyroiditis, and the likelihood of abnormal thyroid function increased with age. ${ }^{4}$ The antibody results $(29 \%$ positive) in our patients compared with the $40 \%$ positive in residents of a big mental institution in Italy ${ }^{5}$ are interesting. Our treatment of the grossly hypothyroid group was most gratifying to parents and supervisors in the adult training workshops. To quote a parent: "Instead of a vegetable you have got a person." The dwarfed teenage girls grew in height and lost their obese, coarse appearance. All became more active and alert, and the whole quality of their lives improved.

We thank Dr Jean Brown and her laboratory staff for the radioimmunoassays and Professor RS Illingworth for his advice.

1 Aarskog D. Autoimmune thyroid disease in children with mongolism Arch Dis Child 1969;44:454-60.

2 Sare Z, Ruvalcaba RHA, Kelley VC. Prevalence of thyroid disorder in Down's syndrome. Clin Genet 1978;14:154-8.

3 Daniels DM, Simon JL. Down's syndrome, hypothyroidism and diabetes mellitus. F Pediatr 1968;72:697-9.

- Baxter RC, Larkins RC, Martin FIR, Heyma P, Myles K, Ryan L. Down's syndrome and thyroid function in adults. Lancet 1975 ;ii:794-6.

- Burgio GR, Ugazio AG. Immunity in Down's syndrome. Eur $\mathcal{F}$ Pediatr 1978;127:293-4

(Accepted 1 February 1980)

Luton and Dunstable Hospital, Luton, Bedfordshire LU1 3UF

E DE H LOBO, FRCPED, DCH, consultant paediatrician

Bedfordshire Area Health Authority, Luton, Bedfordshire

$M$ KHAN, MB, DCH, senior clinical medical officer

$\mathrm{J}$ TEW, MB, DCH, senior clinical medical officer

Clinical findings before and after treatment in seven patients with gross hypothyroidism and Down's syndrome

\begin{tabular}{|c|c|c|c|c|c|c|c|c|c|c|c|c|}
\hline \multirow{3}{*}{ Case No } & \multirow{3}{*}{ Age } & \multirow{3}{*}{ Sex } & \multicolumn{8}{|c|}{ Before treatment } & \multicolumn{2}{|c|}{ After treatment } \\
\hline & & & \multirow{2}{*}{$\begin{array}{l}\text { Urine } \\
\text { glucose }\end{array}$} & \multirow{2}{*}{$\begin{array}{c}\text { Height } \\
(\mathrm{cm})\end{array}$} & \multirow{2}{*}{$\begin{array}{c}\text { Weight } \\
(\mathbf{k g})\end{array}$} & \multirow{2}{*}{$\underset{(\mathrm{nmol} / \mathrm{l})}{\mathrm{T4}}$} & \multirow{2}{*}{$\underset{(\mathrm{mU} / \mathrm{l})}{\mathrm{TSH}}$} & \multicolumn{2}{|c|}{ Antibodies } & \multirow{2}{*}{$\begin{array}{c}\text { Thyroxine } \\
\text { dosage } \\
(\mu g)\end{array}$} & \multirow{2}{*}{$\underset{(\mathrm{cm})}{\text { Height }}$} & \multirow{2}{*}{$\underset{(\mathrm{kg})}{\text { Weight }}$} \\
\hline & & & & & & & & $\begin{array}{c}\text { TGA } \\
\text { (dilution) }\end{array}$ & $\underset{\text { (dilution) }}{\text { AMS }}$ & & & \\
\hline & & & & & & & & & & & \multicolumn{2}{|c|}{1 year later } \\
\hline \multirow[t]{2}{*}{$\begin{array}{l}1 \\
2 \\
3\end{array}$} & $\begin{array}{l}15 \\
16 \\
11\end{array}$ & $\begin{array}{l}F \\
F \\
M\end{array}$ & \pm & $\begin{array}{l}115 \\
110 \\
125\end{array}$ & $\begin{array}{l}28 \cdot 2 \\
30 \cdot 9 \\
27 \cdot 0\end{array}$ & $\begin{array}{r}3 \\
24 \\
16\end{array}$ & $\begin{array}{l}>50 \\
>50 \\
>50\end{array}$ & $\begin{array}{l}+, 1 / 6400 \\
+, 1 / 100 \\
+, 1 / 400\end{array}$ & $\begin{array}{c}+, 1 / 6400 \\
-\end{array}$ & $\begin{array}{l}200 \\
200 \\
100\end{array}$ & $\begin{array}{l}126 \\
119 \cdot 5 \\
132 \cdot 5\end{array}$ & $\begin{array}{l}28 \cdot 6 \\
25 \cdot 4 \\
29 \cdot 5\end{array}$ \\
\hline & & & & & & & & & & & $3 m o$ & \\
\hline \multirow[t]{2}{*}{$\begin{array}{l}4 \\
5 \\
6\end{array}$} & $\begin{array}{l}37 \\
38 \\
29\end{array}$ & $\begin{array}{l}\mathrm{F} \\
\mathrm{F} \\
\mathrm{M}\end{array}$ & $\bar{z}$ & $\begin{array}{l}132.5 \\
145 \\
152.5\end{array}$ & $\begin{array}{l}48 \cdot 1 \\
76 \cdot 3 \\
61 \cdot 3\end{array}$ & $\begin{array}{l}56 \\
10 \\
48\end{array}$ & $\begin{array}{r}23 \\
>50 \\
35\end{array}$ & $\begin{array}{l}+, 1 / 400 \\
+, 1 / 400 \\
+, 1 / 25600\end{array}$ & $\bar{z}$ & $\begin{array}{l}100 \\
150 \\
100\end{array}$ & $\begin{array}{l}\text { No change } \\
\text { No change } \\
\text { No change }\end{array}$ & $\begin{array}{l}46 \cdot 2 \\
69 \cdot 8 \\
60 \cdot 7\end{array}$ \\
\hline & & & & & & & & & & & \multicolumn{2}{|c|}{4 months later } \\
\hline 7 & 25 & $\mathbf{M}$ & - & $147 \cdot 5$ & $117 \cdot 7$ & 48 & 33 &,$+ 1 / 1600$ & - & 200 & No change & $108 \cdot 8$ \\
\hline
\end{tabular}

T4 $=$ Thyroxine. TSH $=$ Thyrotrophin. TGA $=$ Thyroglobulin antibodies. AMS $=$ Automicrosomal antibodies

Conversion: SI to traditional units-T $4: 1 \mathrm{nmol} / 1 \approx 0.08 \mathrm{mg} / 100 \mathrm{ml}$. 